\title{
Art? Science? .... Alchemy: The materiality of spiritual expression in artistic creation revealed through the analytical techniques of a heritage conservator
}

\author{
Maggi Loubser \\ School of the Arts, University of Pretoria, South Africa \\ Email: maggi.loubser@up.ac.za \\ Orcid: https://orcid.org/0000-0001-6737-2317 \\ Salome le Roux \\ School of the Arts, University of Pretoria, South Africa \\ Email: salome@arte.co.za
}

Doi: https://doi.org/10.46222/pharosjot.102.114

\begin{abstract}
To the uninitiated, it is quite probable that the results that art conservators derive from analytical techniques, may resemble alchemy, but they do not create gold from lead. Instead, they represent the composition of an object as its chemical components. X-ray fluorescence spectroscopy (XRF) has long been used for the compositional determination of minerals and metals in the mining and manufacturing industries, and over the past few years the applications in art and conservation increased rapidly. In addition, technical photography (in which filtering determines which wavelengths of light reach the camera) has the ability to create a new art form - one that, apart from being visually appealing, can provide information on the materials which had been used by the artist. In this manner, a whole new layer of information may be revealed, adding to the aesthetic and spiritual impact of the work. In this article, two objects of African art, namely a century-old prayer scroll from Ethiopia and a twodecades old sculpture by South African artist Lucky Sibiya, are investigated to see if this 'alchemy' can reveal that which even the artists were unaware of.
\end{abstract}

Keywords: Ethiopian prayer scrolls, The Sun Man (1995) by Lucky Sibiya, X-ray fluorescence spectroscopy, ultraviolet-induced visible fluorescence photography, reflected infrared photography, tangible heritage conservation.

\section{Introduction ${ }^{1}$}

"Alchemy is a science tinged with spirituality and infused with a schpritz of artistic spirit." (David Brafman - Getty Conservation Institute 2016).

Each artifact has a backstory that adds to the biography of the object (Hamilton 2017: 350) whether the artist's muse or the environment and resources that were available to the maker. Alchemy was the foundation of modern chemistry; only in the seventeenth and eighteenth centuries did scientists such as Robert Boyle (1627-1691) and Antoine Lavoisier (1743-1794) begin to reshape the old alchemical traditions into a rigorous scientific discipline (Principe, DeWitt \& Chemical Heritage Foundationv,2002: 4). Over the past few years, analytical

\footnotetext{
${ }^{1}$ The financial support of the South African National Institute for the Humanities and the Social Sciences (NIHSS) is gratefully acknowledged. (Project CRP20-1032: African oral art in image-text objects: Cultural translations of precolonial memories and remains).
} 
techniques (which, to the uninitiated might resemble alchemy) have increasingly been used to investigate heritage objects.

In the current era, we find ourselves in murky waters with complex problems that cannot always be solved with methodologies that clearly fit into the one or the other discipline, and thus we increasingly turn to more interdisciplinary approaches for our research. The research of the art conservator, while situated in the art world, primarily makes use of scientific methodologies, which are difficult to align with the traditional methods followed in the humanities. The hermeneutic approach probably comes closest, since we make use of scientific tools to identify the materials and the methods used by artists long gone, not only to try and understand the work better, but also to get a glimpse into what the artists' creative thought processes might have been.

In this project, two very different spiritual objects, one a prayer scroll by an unknown Ethiopian dabtara, and the other a carved wooden totem from a well-known South African artist, were investigated by using both technical photography and X-ray fluorescence spectroscopy. The use of the term 'totem' for all his upright three-dimensional works was Sibiya's own borrowing from the Native American context, according to his gallery and two of his solo exhibitions (Everard Read [Sa]). The aim of this investigation was to evaluate the feasibility of these techniques to add further knowledge to the selected items apart from what had already been established about them via 'traditional' art historical procedures.

In current debates, it is increasingly argued that the tangible and intangible significance of an object cannot be separated, and that all heritage should be viewed in a holistic manner (Nilson \& Thorell, 2018). This study attempts to enrich the appreciation of the objects, and to create a greater understanding of the artists' process by producing more information and deepening the insight regarding the materiality of the objects.

\section{Analytical techniques}

The investigative process followed for both case studies was as follows:

\section{Visual inspection by means of magnification and USB microscopy}

To take a closer look, we employed the help of magnification and USB microscopy. Magnification and microscopy "provide information regarding colour, surface finish, degradation and production method", together with important identifying marks, texture, and degradation (Stuart, 2007: 43). In the two case studies, magnification and microscopy were used to study production and painting techniques, substrates, layers, brushwork, cracks, additives (such as fillers), and signatures or writing (Cycleback, 2017: 129). A USB digital microscope with 300x magnification potential and a 5-megapixel image sensor were used in the examination.

\section{Ultraviolet-induced visible fluorescence photography}

The two case studies were exposed to the ultraviolet (UV) radiation from a Q-22 Ultraviolet light with 2 UV Bulbs of 110 Volt that have a peak intensity of $650 \mathrm{microW} / \mathrm{cm}^{2}$ at 6 inches. The bulbs used are BLE-220B and are UVA. Exposure by this lamp causes ultraviolet-induced visible fluorescence - "[f]luorescence is a process in which a material absorbs electromagnetic flux of particular wavelengths and emits radiation at other, longer wavelengths" (JohnstonFeller, 2001: 205). Thus, certain materials are excited, causing them to emit characteristic visible fluorescence, which is used to identify specific pigments, varnishes, adhesives, and recent restorations. Ultraviolet-induced visible fluorescence photography is the capturing of photographs with a digital camera while the object is illuminated with the aforementioned UV lamps (Frey, Heller, Kushel, Vitale, \& Weaver, 2008: 154-157). The camera had a UV pass filter with IR blocking capability (the X-Nite 330nm Coated Filter). 


\section{Reflected infrared photography}

With visible light-induced reflected infrared photography, different wavelengths of infrared can be allowed to pass through the lens of a camera. This makes subsurface layers of the artwork visible. This information allows the investigator to see whether the creators of the art objects might have made underdrawings or changed their minds about an element that is now overpainted or erased from sight. The case studies were illuminated with two visible-light sources that contain the infra-red-light spectrum. Infra-red radiation can be photographed through a visible-light blocking filter and an infra-red passing filter (the visible light filter is an X-Nite Band Pass Series 1 (BP1) $320-670 \mathrm{~nm}$; and the infrared filters are X-Nite 715nm, XNite $850 \mathrm{~nm}$ and X-Nite $1000 \mathrm{~nm}$ ). In reflected infra-red digital photography, the light source is reflected from the surface and the images produced often reveal hidden elements that are not visible to the naked eye under normal illumination. These elements are clues to technique, authorship, restoration, and original or supplementary additions.

\section{$X$-ray fluorescence spectroscopy $(X R F)$}

XRF was performed to learn about the pigments that were likely to have been used in the production of the artworks. Non-invasive and non-destructive XRF provides information regarding elemental composition of each area studied - thus, about the elements present in the paint layers on the surface and below. The presence of specific elements provides an indication of the pigments that are present in the examined area(s). The presence of specific pigments may be inferred from the detection of elements or combination of elements with different degrees of certainty, as some elements or combination of elements may be characteristic of multiple pigments (Bezur \& Sperber, 2016: 5). ${ }^{2}$

A Bruker Tracer $5 \mathrm{i}$ handheld X-ray fluorescence spectrometer was used to perform nondestructive elemental analysis in the locations indicated. The spectrometer is equipped with a rhodium (Rh) X-ray tube. Spectra were acquired for 90 seconds live time using $40 \mathrm{kV}$ accelerating potential, $5 \mu \mathrm{A}$ current, and without any beam filters. Air-path XRF instruments, such as the one used in this analysis, are generally not able to detect the low energy $\mathrm{X}$-rays emitted by elements with atomic number lower than $\sim 12$, so elements such as carbon, nitrogen, oxygen, and sodium cannot be detected. (Bezur, Lee, Loubser \& Trentelmann, 2020).

\section{The first case study: an Ethiopian prayer scroll (Figures 1 and 2)}

For many centuries, Ethiopian prayer scrolls were believed to carry "magical" healing powers, and the owners invariably carried them on their person - specifically around their necks. A dabtara, or ordained cleric, made each scroll with a specific individual's physical and spiritual characteristics in mind. These scrolls are a good example of the integration between indigenous belief and Christian religion, because the texts were often taken from religious sources, such as the Gospel. This led to the Ethiopian Church overlooking the magical practices connected to the making and wearing of these scrolls (Steyn, 2012).

The dabtara would sacrifice an animal, wash the 'client' in the animal's blood for purification, and create the scroll from the animal's hide. The hide would be manufactured into parchment and cut into strips. Three strips were then stitched together to form a scroll the length of the 'client's' height. The writing on the scrolls is all in black and red ink, and legend would have it that the red is the sacrificial animal's blood (Steyn, 2012).

\footnotetext{
${ }^{2}$ Conclusive pigment identification requires complementary analysis via a compound-specific technique such as X-ray diffraction (XRD) or Raman spectroscopy.
} 


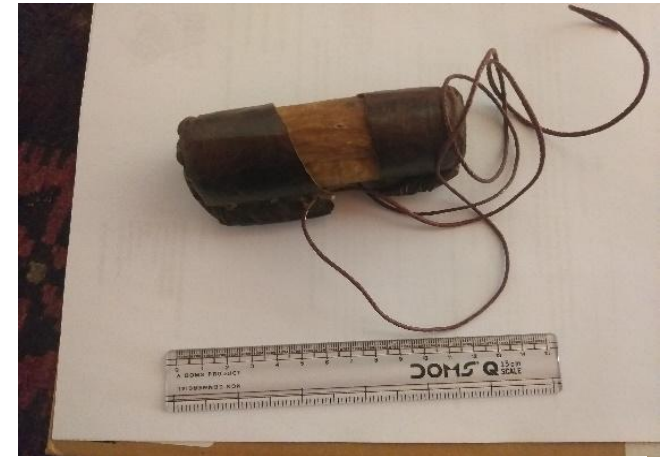

Figure 1: Case study one: rolled-up Ethiopian prayer scroll. Private collection. Photograph by authors, 2020

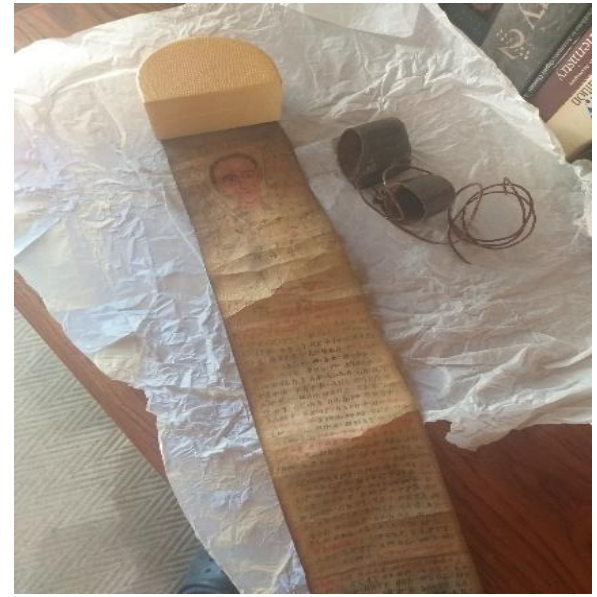

Figure 2: case study one: rolled open Ethiopian prayer scroll. Private collection. Photograph by authors, 2020

The Ethiopian scroll used in this case study is estimated to date from the late nineteenth or early twentieth century. It consists of three sections sewn together, written in one column with 161 lines. When the scroll is rolled open, it measures $1695 \times 95 / 105 \mathrm{~mm}$, and the different sections are $635 \times$ 95/105 mm, $755 \times 105 \mathrm{~mm}$ and $305 \times 105 \mathrm{~mm}$.

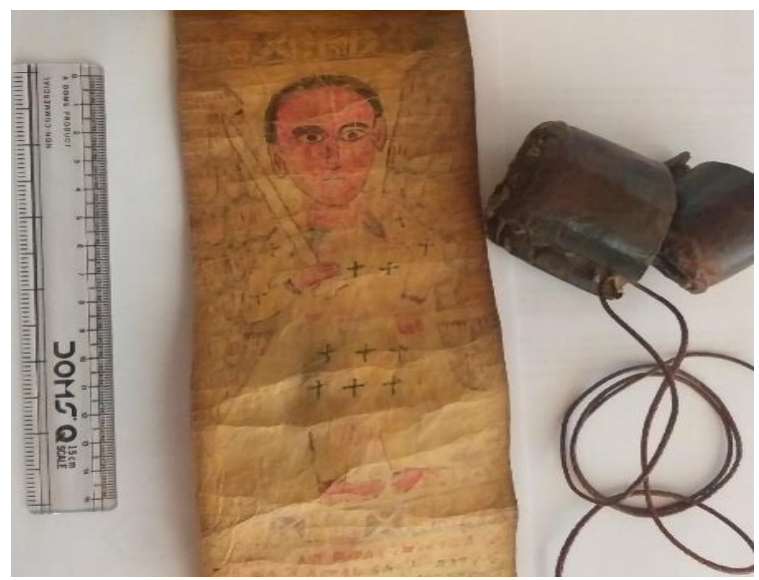

Figure 3: Case study one: rolled open Ethiopian prayer scroll.

Private collection. Photograph by authors, 2020).

Visual inspection is the first step in a technical investigation of artefacts, and to enhance our ability to see we often use microscopy, as seen in the following microscopy pictures (Figure 4) where a 300x magnification was used: Under magnification, the texture of the parchment is clearly seen - and also the damage. A scroll such as this was intended for permanent wear, close to the human body with the associated humidity and oil which kept the leather healthy. This scroll is now housed in a closed box, and there are small cracks appearing in the folds. Over time, the ink leached, and an imprint of the lettering and drawing can be seen on the opposite side of the scroll as it was transferred while being rolled. The second figure shows how the ink penetrated the parchment, which probably assists with its longevity. 


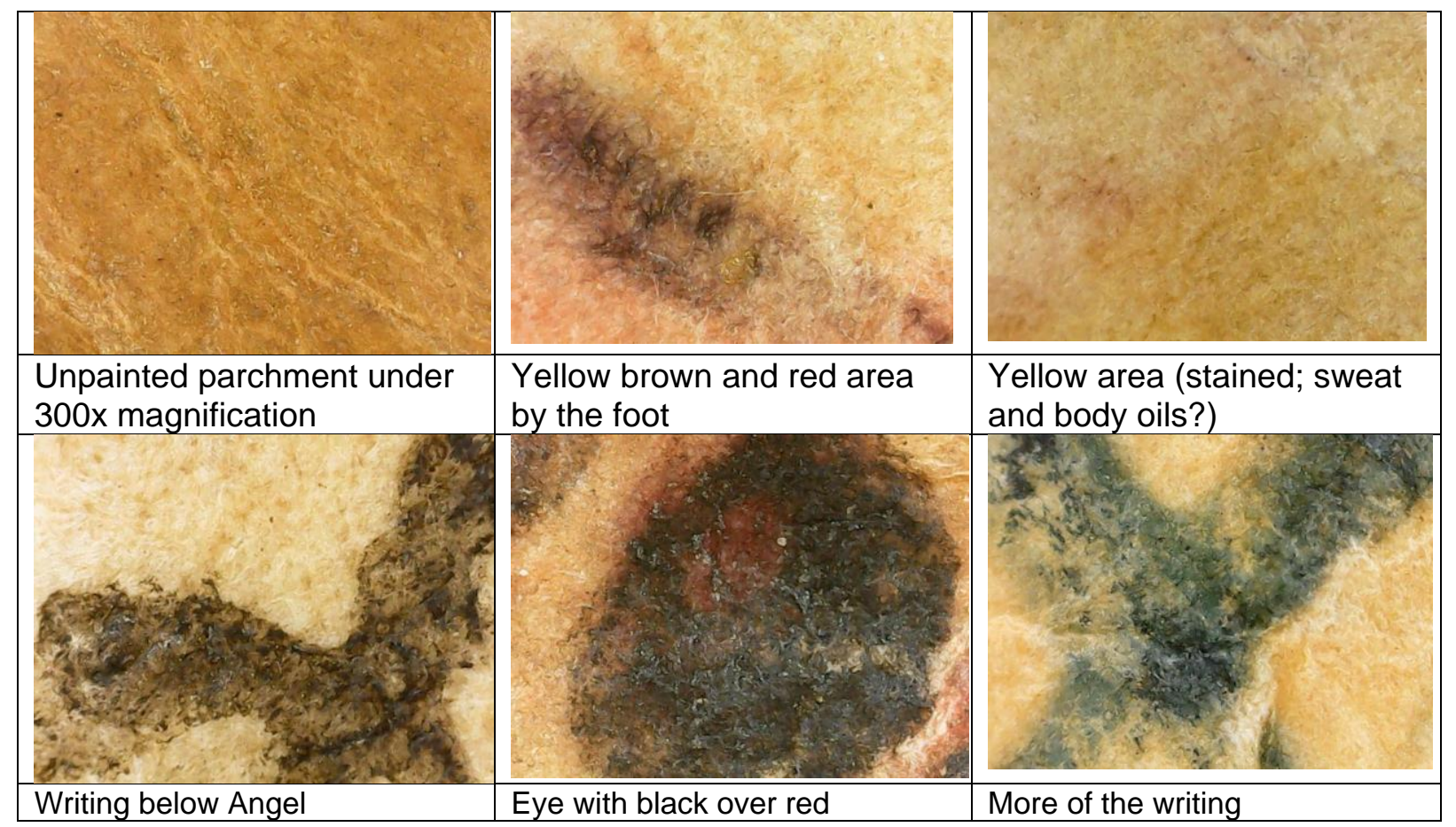

Figure 4: USB microscopy images of six locations on the Ethiopian prayer scroll.

Our findings reveal something about the biography of this scroll: it had indeed been in use. There are definite signs of sweat and body oils in the yellow-coloured areas, as the only colours used traditionally by the makers of such scrolls were black and red. In the microscope photo of the eye, the method of the artist is revealed as one can see that the black ink was applied over the red ink.

X-ray fluorescence spectroscopy is a non-destructive analytical method during which the object is irradiated with X-rays - just like a medical X-ray. Instead of using a film to measure the contrast between bone and flesh (such X-ray imaging is also used extensively in conservation), a detector measures the characteristic X-ray photons emanating from the object. When the object is irradiated, all the atoms in the object are excited, and when they relax back to their ground state, they emit an X-ray photon with a characteristic wavelength, and so we can identify the elements in a material. We can use this technique for elements between magnesium and uranium in the periodic table. It cannot, however, analyse organic materials that consist mostly of carbon $(C)$, hydrogen $(H)$, oxygen $(O)$, and nitrogen $(N)$.

In Figure 5, the blue spectrum was collected from the white wing area and the red spectrum from the red face area on the scroll. Both are very similar in displaying the presence of chlorine $(\mathrm{Cl})$, potassium $(\mathrm{K})$, calcium $(\mathrm{Ca})$, and Iron $(\mathrm{Fe})$. The intensities differ, but that could be a function of the sample presented to the spectrometer. Thus, we can conclude that these elements seem to be inherent in the parchment. Calcium $(\mathrm{K})$ could be indicative of bone black - but since this is present in both the wings and the face area, it seems more feasible that an organic black ink was used. Chalk is used in the preparation process of parchment to make it absorbent for the ink, so it is probably this that accounts for its presence. There is no cadmium $(\mathrm{Cd})$ or mercury $(\mathrm{Hg})$ that could indicate a red mineral pigment, and the iron (Fe) peak is present in both the wing and the face area. It is not high enough to suggest that blood was used as red dye, as legend would have it. The fact that the red is still 'very red' and did not oxidise and discolour to brown over time, substantiates this deduction. A possible organic dye could be carmine red, which is produced from the cochineal insect, but on the red spectrum a 
Bromine $(\mathrm{Br})$ peak is observed, which is not present in the white background. This could indeed indicate some organic AZO dyes (Chatwal and Arora. 2009:140) that sometimes

Ethiopian Scroll

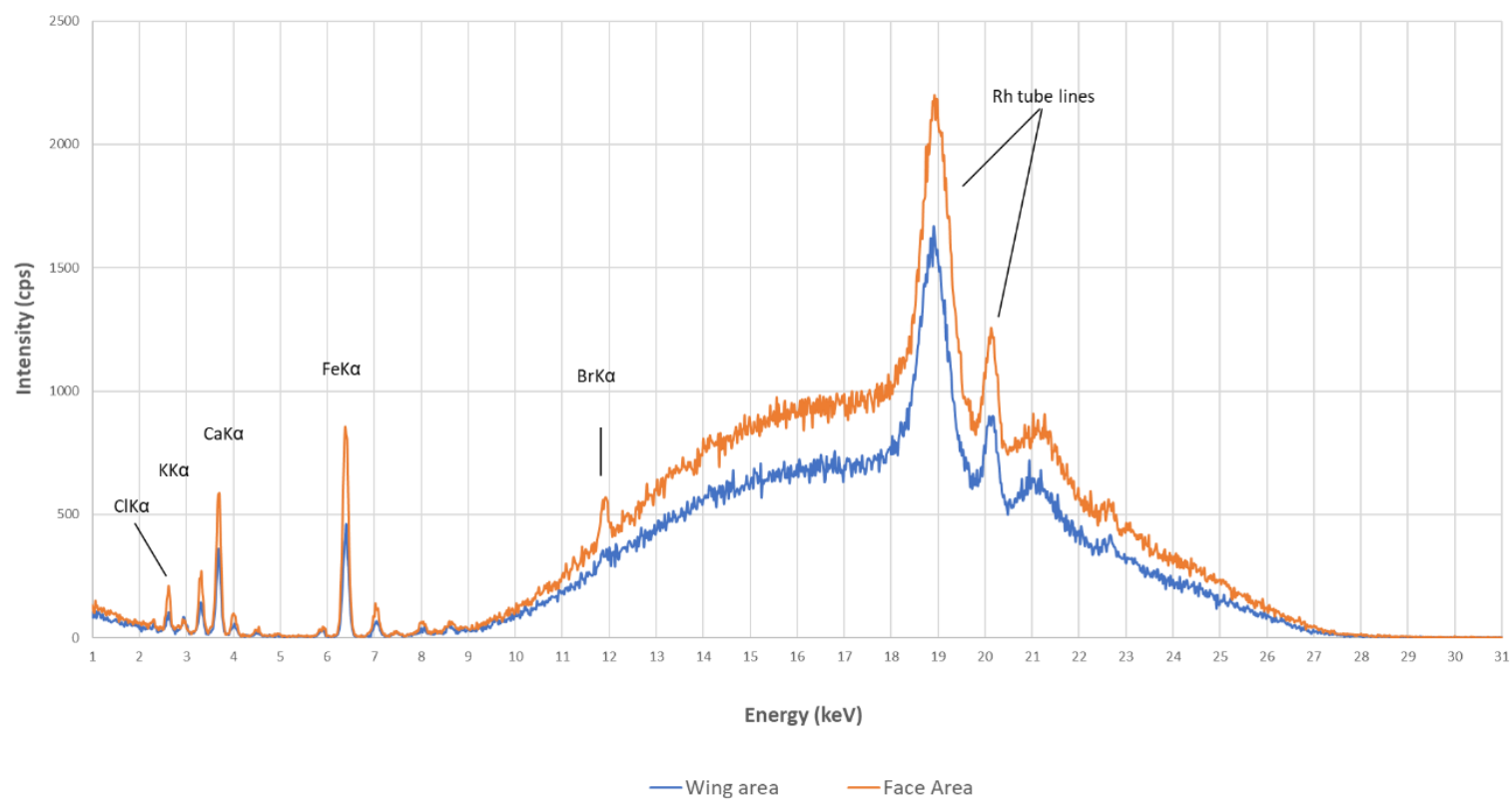

Figure 5: Elemental peaks of two locations on the Ethiopian prayer scroll.

contain bromide (Br). (Red144).

Infra-red imaging is usually used to provide information on underdrawings that are not visible in the upper layer of a painting. Infra-red waves are absorbed by carbon-based pigments/pencils, which create dark areas in IR reflected and transmitted images. We used the technique because a strongly absorbed black ink would confirm Carbon Black, which we could not identify with the XRF. We were specifically interested to confirm the presence of bone black, as these were the natural organic ink pigments used at the time that we were expecting to find.

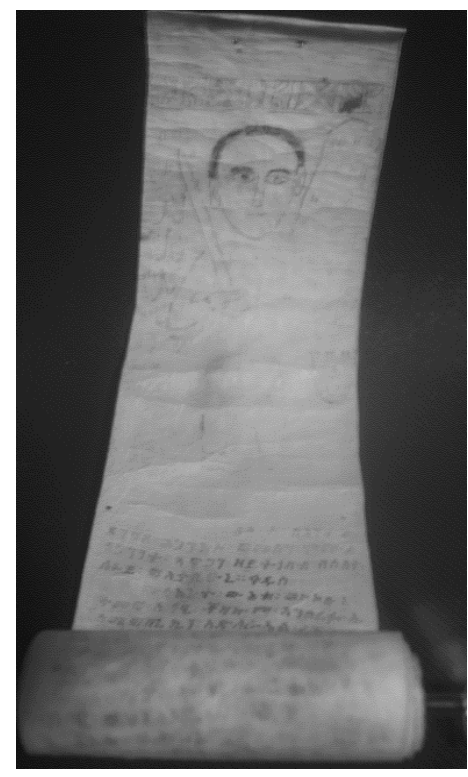

Figure 6: Reflected IR photograph of the Ethiopian prayer scroll. 


\section{The second case study is a South African Totem by Lucky Sibiya, The Sun Man (1995) (Figure 7).}

Lucky Madlo Sibiya was a South African artist who lived between 1942 and 1999. For her Master's project in Tangible Heritage Conservation, Salomé le Roux (2020) conducted a technical study of some of his artworks in the collection of the University of Pretoria in order to investigate the materials and techniques Sibiya used for his carved and painted wood panel artworks. Our second case study discusses one of the artworks from this technical study. Sibiya was the son of a sangoma, and his work was deeply spiritual. He used themes from Zulu mythology, traditions, and customs he had learned from childhood through his experiences of his father's sangoma practices. Sibiya's art technique evolved from shallow relief engravings to carvings of wood and wood panels (towards the end of the 1970s). His engraved and carved artworks are more than mere decorations they are closer to the process of sculpture (Anonymous, 1996: [sp]). They are conceptually abstract visions, created by "rubbing powdered pigments" onto, and into, his creations (Everard Read [sa]).

As seen in Figure 7, his palette is populated by reds, ambers, blues, and browns, with occasional accents of green and white (Mdanda, 2007: 166). Sibiya used black to enhance the bold shapes of his designs, and the colours were applied onto the wood - which almost appears like a patina. The bold black areas are juxtaposed with patterned areas of colour, which binds the composition together. His use of colour, which is warm, sensual, rich and vibrant, is in harmony with the texture and colour of the wood substrates and does not dominate the natural surface and appearance of the substrates.

Magnification and USB microscopy (Figures 8 and 9):

Location 1 reveals the light blue that was also applied first under the dark blue in the mid-section. It is also evident that the black was applied onto the light blue with a roller after the blue had dried. Location 2 shows clear brush strokes, as well as the 'bubbly' textured paint to the right of the image. Location 3 is the midsection where it appears that the paint is flaking, but the closeup with the USB microscope shows that the edges of the orange are intact; the effect in this area was therefore intentional. mixed with a substance. Location 5, at the right-hand edge of the artwork, is an example of distinguishing between the sequence of the paint application - here it was first the black, then brown, then the yellowish ochre. Location 6 , in a groove between the left leg and the phallus, revealed a chalky, flaking gypsum that is also found on other Sibiya artworks, such as The Doorhandle (1987) - also in the University of Pretoria Art Collection. Location 7, an interior focus of the wooden bed, revealed a tiny, dead spider stuck in its web, while location 8 is a spider web on the exterior of the right leg. 


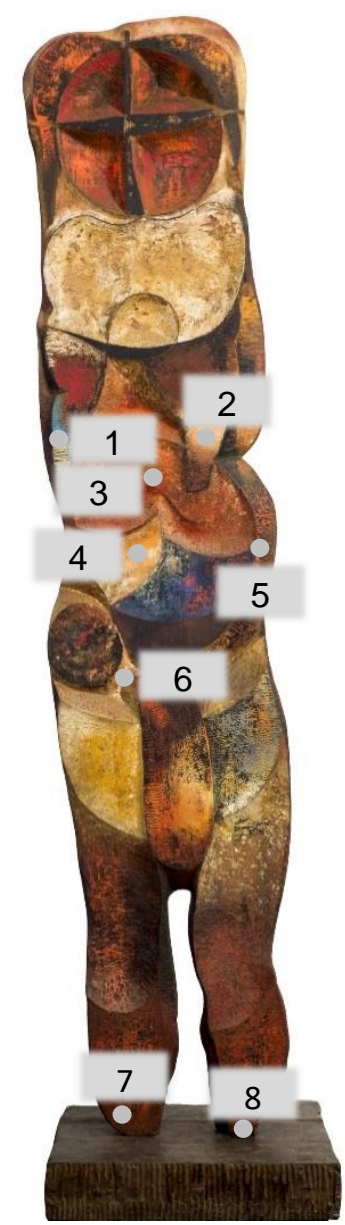

Figure 8: Reference image of USB digital microscope locations on The Sun Man (1995).

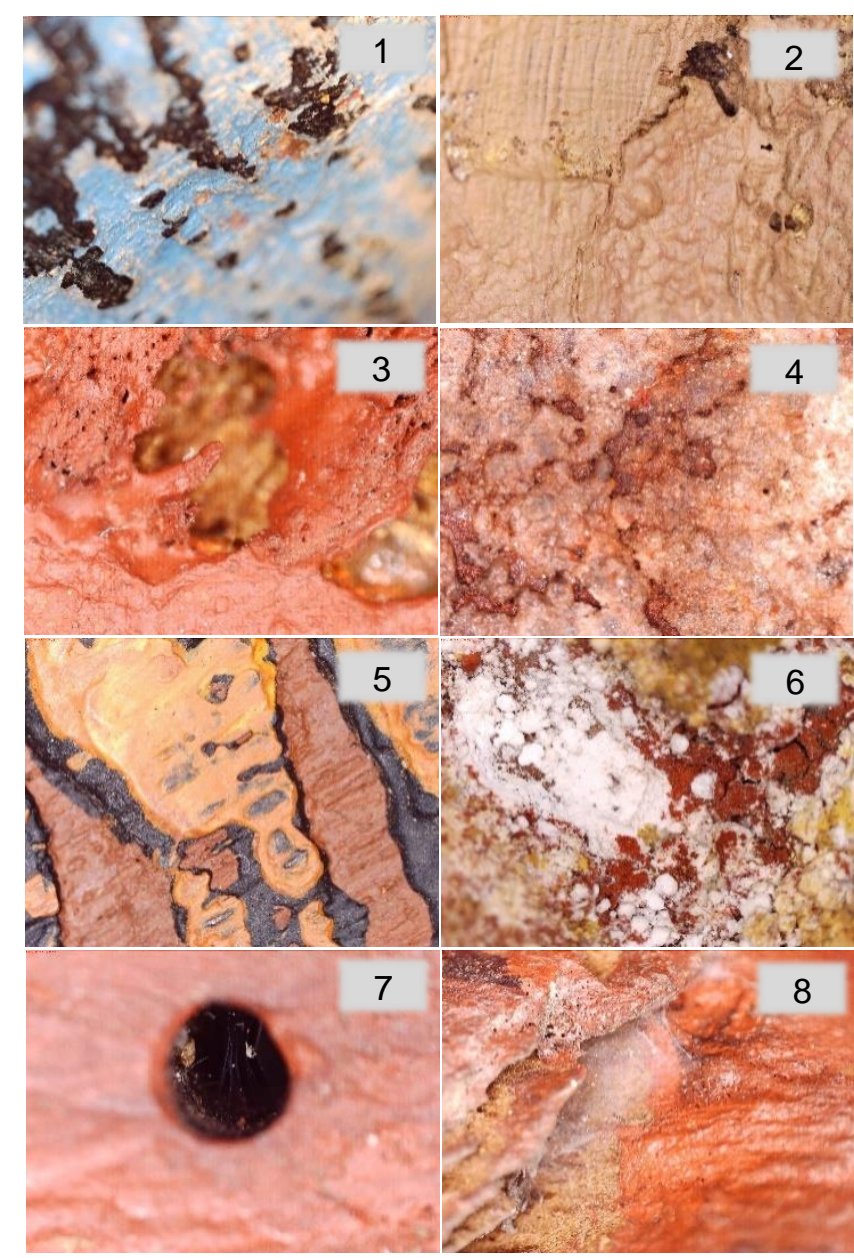

Figure 9: Close-up images of details observed with a USB digital microscope on The Sun Man (1995).

The procedure and findings from the ultraviolet-induced visible fluorescence photography (Figures 10,11 and 12), can be noted as follows: Because The Sun Man was on exhibition and could not fit into the photography studio, the artwork was covered with a big blanket in the exhibition gallery and close-up UV induced photographs were taken on site. Figure 10 shows that The Sun Man is full of dust and other organic speckles that fluoresce bluish-purple. Figure 11 shows an orange fluorescence to the left of the right arm, which is an ochre colour in visible light, and the circular shapes that fluoresce greenish white are the exposed wooden substrate. Figure 12, the orange area in the middle of the artwork that is intentionally textured, fluoresces red, and the white speckles fluoresce a bright white. The white speckles might be the chalk, gypsum, or marble dust found with XRF Spectroscopy. 


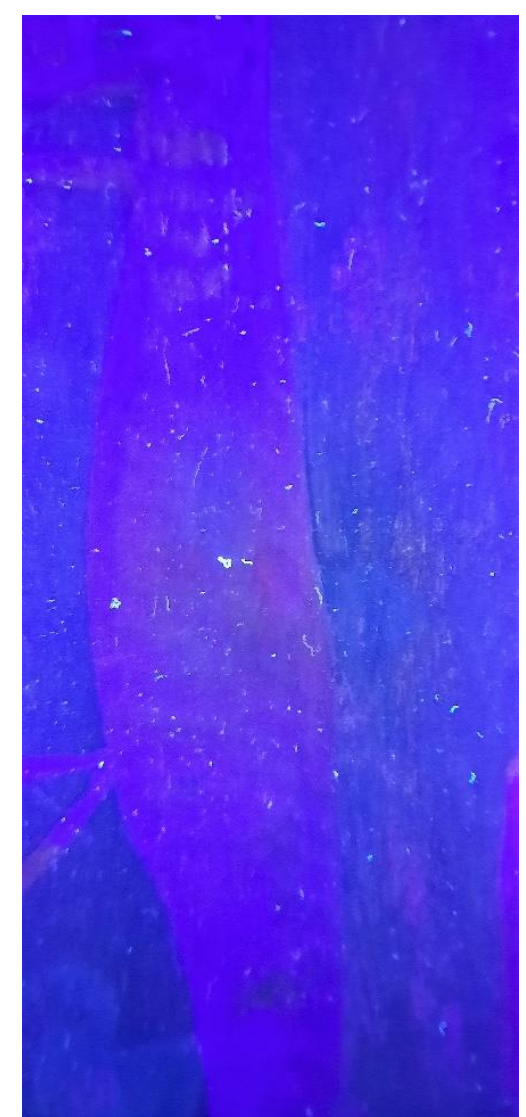

Figure 10: Underneath the blue area in the middle of The Sun Man (1995).

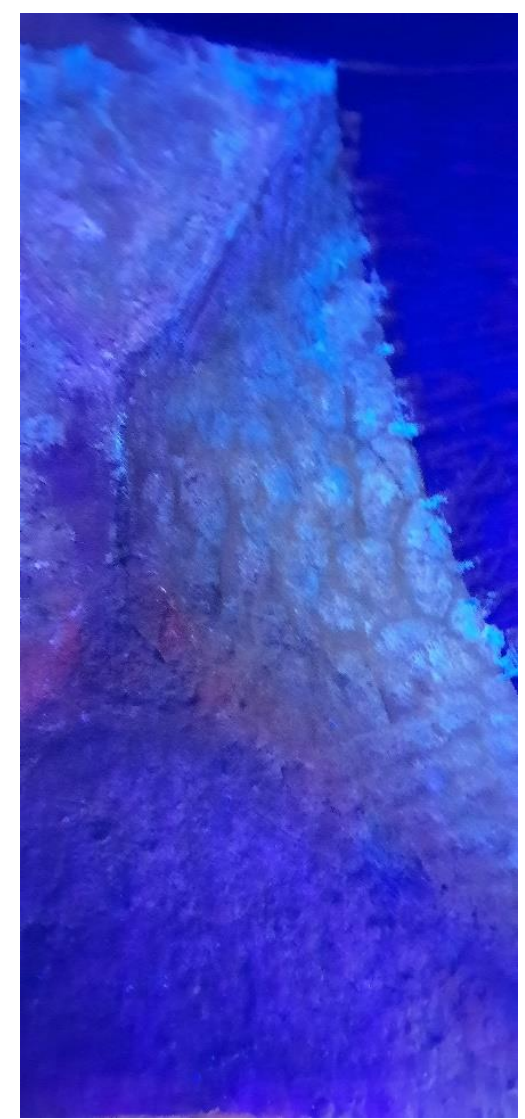

Figure 11: The area between the two arms of The Sun Man (1995).

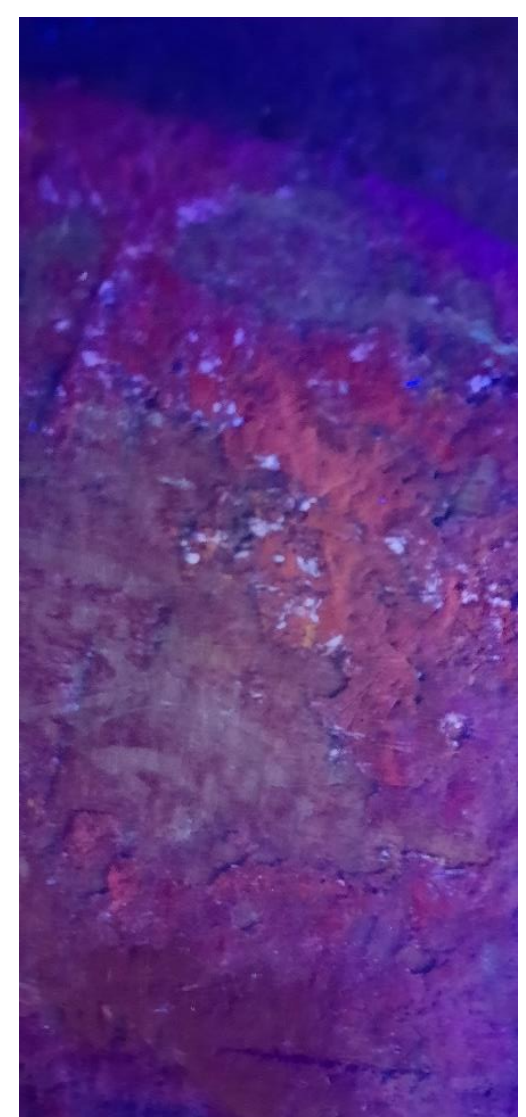

Figure 12: Orange area with white spots on The Sun Man (1995).

Subsequently, the procedure of reflected infrared photography was applied. The Sun Man was photographed with a Canon 6D 20.2 Megapixel Camera with UV-VIS-IR Functionality, the Canon EF 24-70mm f/2.8L II USM lens, and the necessary filters. ${ }^{3}$ Only close-up images were possible, and they reveal some interesting aspects. Figure 13, the cadmium red signature on the right leg, reflects the IR wavelengths with the $850 \mathrm{~nm}$ filter and the $1000 \mathrm{~nm}$ filter, but interestingly, less with the $715 \mathrm{~nm}$ filter. Figures 14, 15, and 16 reveal no underdrawings or guidelines. The lighter scratches on the darker areas are the exposed wood which reflect, while the paints absorb relatively more.

\footnotetext{
${ }^{3}$ Infra-red radiation can be photographed through a visible-light blocking filter and an infra-red passing filter (the visible light filter is an X-Nite Band Pass Series 1 (BP1) $320-670 \mathrm{~nm}$, and the infrared filters are X-Nite 715nm, X-Nite 850nm and X-Nite 1000nm).
} 


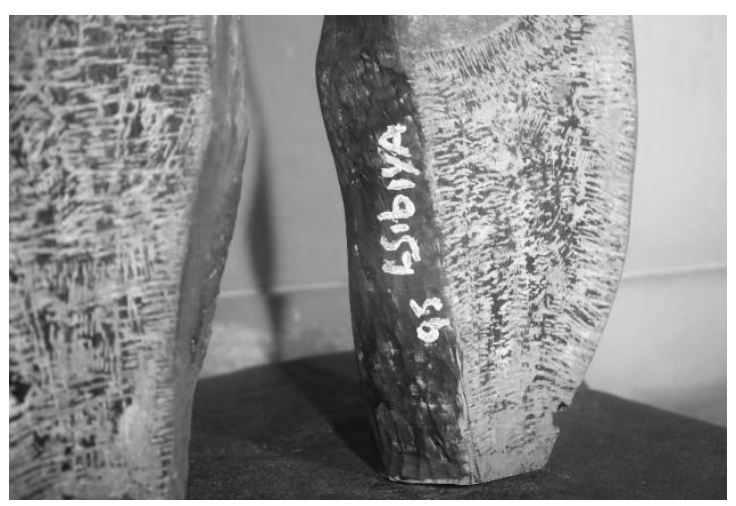

Figure 13: The signature of The Sun Man (1995) with the 850nm filter.

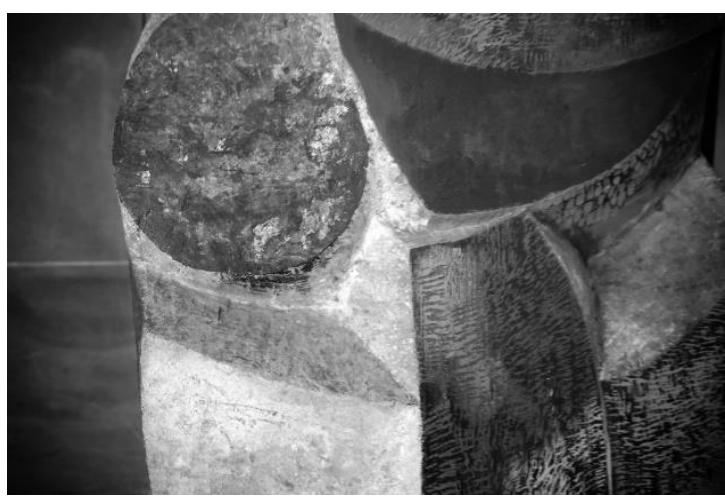

Figure 14: The area above right leg of The Sun Man (1995) with the 850nm filter.

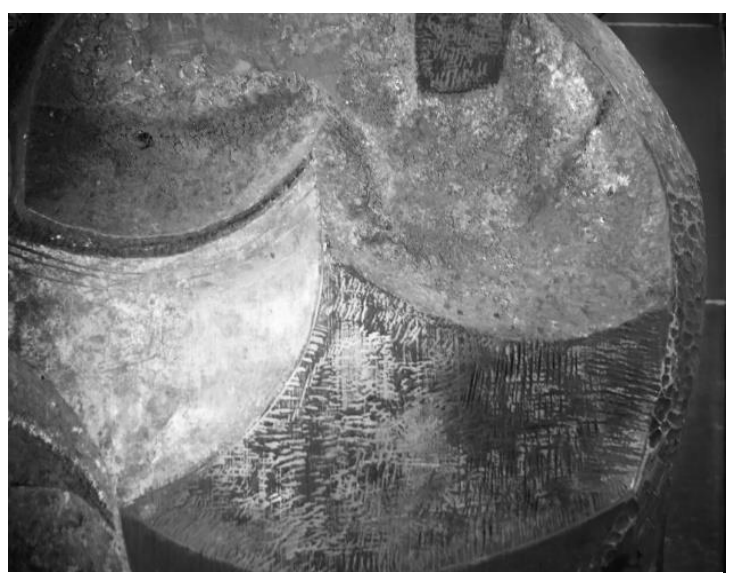

Figure 15: The middle section of The Sun Man (1995) with the 1000nm filter.

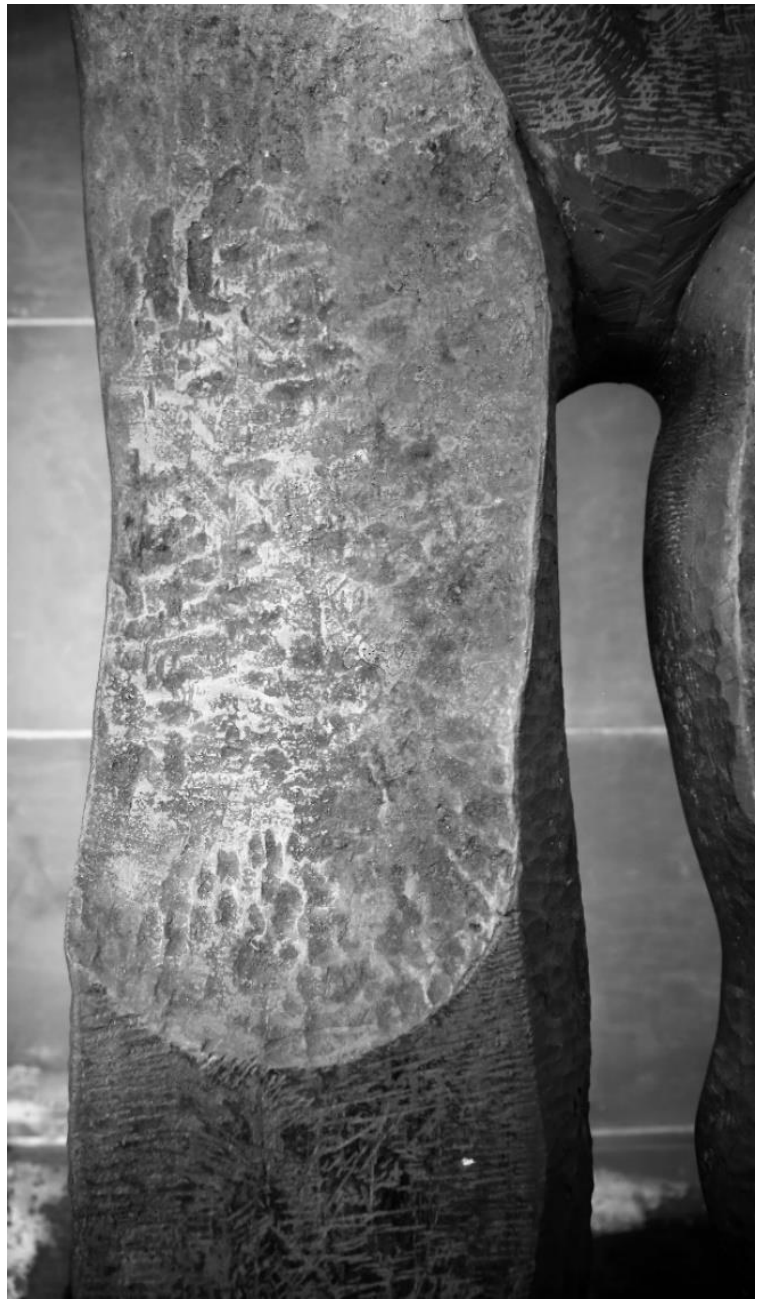

Figure 16: The left leg of The Sun Man (1995) with the $1000 \mathrm{~nm}$ filter.

As a next step, a non-destructive XRF analysis was performed on nineteen target areas in an attempt to determine the pigments used by Sibiya. In summary, XRF data suggest the strong presence of cadmium red, cadmium yellow, bone/ivory black, titanium white, ochres, sienna, and umbers. 


\begin{tabular}{|c|c|c|c|}
\hline Location & Description & $\begin{array}{l}\text { Primary elements } \\
\text { detected }\end{array}$ & Possible colourants \\
\hline D1 & Orange & $\begin{array}{l}\text { Cd, Se, Sn, Ti, Ba, Ni, } \\
\mathrm{Cu}, \mathrm{Zn}, \mathrm{Sr}\end{array}$ & $\begin{array}{l}\text { Cadmium red, cadmium yellow, lead tin } \\
\text { yellow, titanium white, barium sulphate }\end{array}$ \\
\hline D2 & Black & $\begin{array}{l}\text { Ti, Ba, Ca, } \mathrm{Sn}, \mathrm{Ni}, \mathrm{Cu} \\
\mathrm{Zn}, \mathrm{Fe}\end{array}$ & $\begin{array}{l}\text { Bone black, ivory black, barium } \\
\text { sulphate, titanium white }\end{array}$ \\
\hline D3 & Red & $\begin{array}{l}\mathrm{Cd}, \mathrm{Se}, \mathrm{Ba}, \mathrm{Sn}, \mathrm{Sr}, \mathrm{Fe}, \\
\mathrm{Ni}, \mathrm{Cu}, \mathrm{Zn}\end{array}$ & Cadmium red, barium sulphate, \\
\hline D4 & Filling & $\begin{array}{l}\mathrm{Fe}, \mathrm{Ca}, \mathrm{Sn}, \mathrm{Ti}, \mathrm{Ba}, \mathrm{Ni} \\
\mathrm{Cu}, \mathrm{Zn}\end{array}$ & Wood putty \\
\hline D5 & Red & $\begin{array}{l}\mathrm{Cd}, \mathrm{Se}, \mathrm{Ba}, \mathrm{Sn}, \mathrm{Fe}, \mathrm{Ni} \\
\mathrm{Cu}, \mathrm{Zn}, \mathrm{Sr}\end{array}$ & Cadmium red, barium sulphate, \\
\hline D6 & Reddish brown & $\begin{array}{l}\mathrm{Fe}, \mathrm{Ca}, \mathrm{Sn}, \mathrm{Ti}, \mathrm{Ba}, \mathrm{Ni} \\
\mathrm{Cu}, \mathrm{Zn}\end{array}$ & Wood putty \\
\hline D7 & Brown & $\begin{array}{l}\text { Fe, Ti, Ba, Cd, Se, Sn, } \\
N i, C u, Z n, S r\end{array}$ & $\begin{array}{l}\text { Mars colours, yellow ochre, red ochre, } \\
\text { Prussian blue, iron black, brown } \\
\text { ochre, umber, sienna, titanium white, } \\
\text { permanent white, barium sulphate, } \\
\text { cadmium red, cadmium yellow }\end{array}$ \\
\hline D8 & Blue & $\begin{array}{l}\text { Ti, Ba, } \mathrm{Sn}, \mathrm{Ca}, \mathrm{Cu}, \mathrm{Ni} \\
\mathrm{Zn}, \mathrm{Fe}, \mathrm{Se}, \mathrm{Sr}\end{array}$ & $\begin{array}{l}\text { Titanium white, barium sulphate, } \\
\text { permanent white, lead tin yellow, chalk, } \\
\text { gypsum, azurite, synthetic copper } \\
\text { blues, blue verditer, indigo, Egyptian } \\
\text { blue, Prussian blue }\end{array}$ \\
\hline D9 & Beige & $\begin{array}{l}\text { Ti, Ba, Fe, Sn, Cd, } N i \\
C u, Z n, S r\end{array}$ & $\begin{array}{l}\text { Titanium white, barium sulphate, } \\
\text { permanent white, yellow ochre, brown } \\
\text { ochre, sienna, umber, mars yellow, } \\
\text { cadmium yellow, lead tin yellow }\end{array}$ \\
\hline D10 & $\begin{array}{l}\text { Orange with } \\
\text { white specs }\end{array}$ & $\begin{array}{l}\text { Ca, Fe, Sn, Ba, Ti, Ni, } \\
\mathrm{Cu}, \mathrm{Zn}, \mathrm{Sr}\end{array}$ & $\begin{array}{l}\text { Chalk, gypsum, yellow ochre, sienna, } \\
\text { mars colours (red and yellow), lead tin } \\
\text { yellow, barium sulphate, titanium white }\end{array}$ \\
\hline D11 & Light orange & $\begin{array}{l}\text { Cd, Se, Ti, Ba, Sn, Fe, } \\
N i, C u, Z n\end{array}$ & $\begin{array}{l}\text { Cadmium red, cadmium yellow, } \\
\text { titanium white, barium sulphate, } \\
\text { permanent white, lead tin yellow, mars } \\
\text { red, and yellow }\end{array}$ \\
\hline D12 & Dark blue & $\begin{array}{l}\text { Ti, Fe, Co, Sn, Sr, Ni, } \\
\mathrm{Cu}, \mathrm{Zn}\end{array}$ & $\begin{array}{l}\text { Titanium white, Prussian blue, mars } \\
\text { black, iron black, cerulean blue, cobalt } \\
\text { blue, cobalt violet, cobalt turquoise light } \\
\text { and dark }\end{array}$ \\
\hline D13 & Yellow & $\begin{array}{l}\text { Cd, Se, Ti, Ba, Fe, Sn, } \\
\mathrm{Ni}, \mathrm{Cu}, \mathrm{Zn}, \mathrm{Sr}\end{array}$ & $\begin{array}{l}\text { Cadmium yellow, cadmium red, titanium } \\
\text { white, barium sulphate, yellow ochre, raw } \\
\text { sienna, mars yellow }\end{array}$ \\
\hline D14 & Black & $\begin{array}{l}\text { Fe, Ti, Ba, Cd, Sn, Ca, } \\
\mathrm{Ni}, \mathrm{Cu}, \mathrm{Zn}, \mathrm{Sr}\end{array}$ & $\begin{array}{l}\text { Iron black, mars black, titanium white, } \\
\text { barium sulphate, permanent white, }\end{array}$ \\
\hline D15 & Yellow & $\begin{array}{l}\mathrm{Fe}, \mathrm{Ca}, \mathrm{Ti}, \mathrm{Ba}, \mathrm{Sn}, \mathrm{Ni} \\
\mathrm{Cu}, \mathrm{Zn}, \mathrm{Sr}\end{array}$ & $\begin{array}{l}\text { Yellow ochre, raw sienna, mars yellow, } \\
\text { chalk, gypsum, titanium white, barium } \\
\text { sulphate, permanent white }\end{array}$ \\
\hline D16 & Dust blue, grey & $\begin{array}{l}\text { Cd, Ti, Ba, Fe, Sr, Sn, } \\
\mathrm{Se}, \mathrm{Ni}, \mathrm{Cu}, \mathrm{Zn}\end{array}$ & $\begin{array}{l}\text { Cadmium red, cadmium yellow, titanium } \\
\text { white, barium sulphate, permanent } \\
\text { white, iron black, mars black }\end{array}$ \\
\hline D17 & White & $\begin{array}{l}\text { Fe, Ca, Ti, Sn, Ba, Ni, } \\
\mathrm{Cu}, \mathrm{Zn}, \mathrm{Pb}, \mathrm{Sr}\end{array}$ & $\begin{array}{l}\text { Mars colours, iron black, bone black, } \\
\text { calcium, gypsum, titanium white, } \\
\text { barium sulphate, permanent white }\end{array}$ \\
\hline D18 & Signature (red) & $\begin{array}{l}\text { Se, Cd, Ti, Ba, Fe, Sn, } \\
\text { Sr, Ni, Cu, Zn }\end{array}$ & $\begin{array}{l}\text { Cadmium red, titanium white, barium } \\
\text { sulphate, red ochre }\end{array}$ \\
\hline D19 & \begin{tabular}{|l|} 
Verso \\
\end{tabular} & $\begin{array}{l}\text { Ti, Cu, Sn, Cd, Ni, Fe, } \\
Z n, P b, S e\end{array}$ & No pigments \\
\hline
\end{tabular}

Table 1: Break-down of elemental peaks at locations, and possible pigments inferred on The Sun Man (1995). 
Location D1 is probably a combination of cadmium red and cadmium yellow. D2, the black cross over the "face" of the Sun Man, is likely a bone or ivory black. Both D2 and D14 are black areas on the artwork. In comparison, D2 does not have the prominent iron and cadmium intensities that D14 exhibits on the spectra (Figure 18). D3 and D5 strongly suggest cadmium red because the cadmium and selenium peaks are the most intense on both spectra (Figure 19). D4 is probably wood putty, which commonly includes calcium carbonate, linseed oil, and a colorant. Location D6 has a very similar spectrum as D4. However, the D4 spectrum has more intense calcium and iron peaks - while D6 has a more intense barium peak (Figure 20).

D7 is a brown area. To achieve a brown hue, it is necessary to mix a primary colour with a complementary colour - and different ratios of each will determine the hue of the brown. Thus, the possible combinations are endless. However, we suspect a hue with iron intensities such as the ochres, sienna, and umbers. The identification of the blue areas was quite difficult. D8 and D12 had higher peaks at areas that do not infer a blue pigment (Figure 21), and at D8 only copper could be a cause for the blue pigment. We also added indigo to the list of possible colourants because although it is an organic pigment and it will not be detected with XRF, it is still a possibility. We also added Egyptian blue because it has prominent elements of calcium, copper, and silicon. In turn, D12 has high peaks at iron and cobalt, which points towards blue hues such as Prussian blue, cerulean blue, and cobalt blue. Location D9, which appears beige or a pale sandy colour, is possibly a combination of titanium white or barium sulphate (white) and an ochre, sienna, or umber. The determination of D10 was also laborious as a result of the white specs in the paint film. The spectrum has intense calcium peaks, which suggests chalk or gypsum as possibilities for the white specs, while the orange hue is possibly ochre, sienna, or a combination of red and yellow mars colours (Figure 22).

The light orange, location D11, indicates a combination of cadmium red, cadmium yellow, titanium white, and barium sulphate. Location D13, a small yellow spot next to the dark blue of location D12, is possibly a cadmium yellow with traces of titanium white and barium sulphate. While D15 is also yellow in normal viewing conditions, this location has more intense iron and calcium peaks than D13. The pigments inferred at D15 for iron are either yellow ochre, raw sienna, or mars yellow, and for calcium chalk and gypsum. Location D16, a dusty, greyish blue area, has titanium, barium, cadmium, iron, strontium, tin, and selenium peaks. It is inferred that the grey hue is a combination of titanium white, barium sulphate, iron black, or mars black.

Location D17 also has a confusing elemental intensity - iron, which is not a primary element for a white pigment (Figure 22). However, the strong calcium, titanium, and barium peaks indicate calcium, gypsum, titanium white, barium sulphate, or permanent white. The signature, D18, is possibly a cadmium red pigment, because the spectrum has high intensity peaks at cadmium and selenium (Figure 19). The verso, D19, presents elemental peaks of titanium, copper, tin, cadmium, nickel, iron, zinc, lead, and selenium (Figure 23), yet the location did not show any colourant or substance under normal viewing conditions. 
Pharos Journal of Theology ISSN 2414-3324 online Volume 102 - Special Ed 1 (2021)

Copyright: @2021 Open Access/Author/s - Online @ http//: www.pharosjot.com

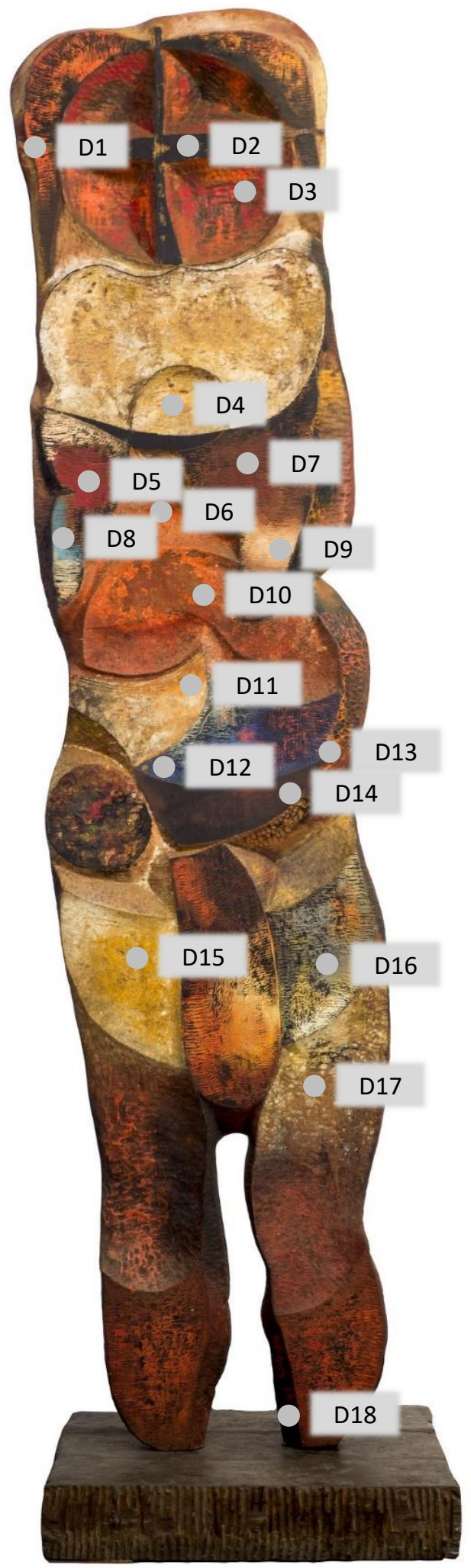

Figure 17: Location of XRF analysis (recto) on The Sun Man (1995). 
Pharos Journal of Theology ISSN 2414-3324 online Volume 102 - Special Ed 1 (2021)

Copyright: @2021 Open Access/Author/s - Online @ http//: www.pharosjot.com

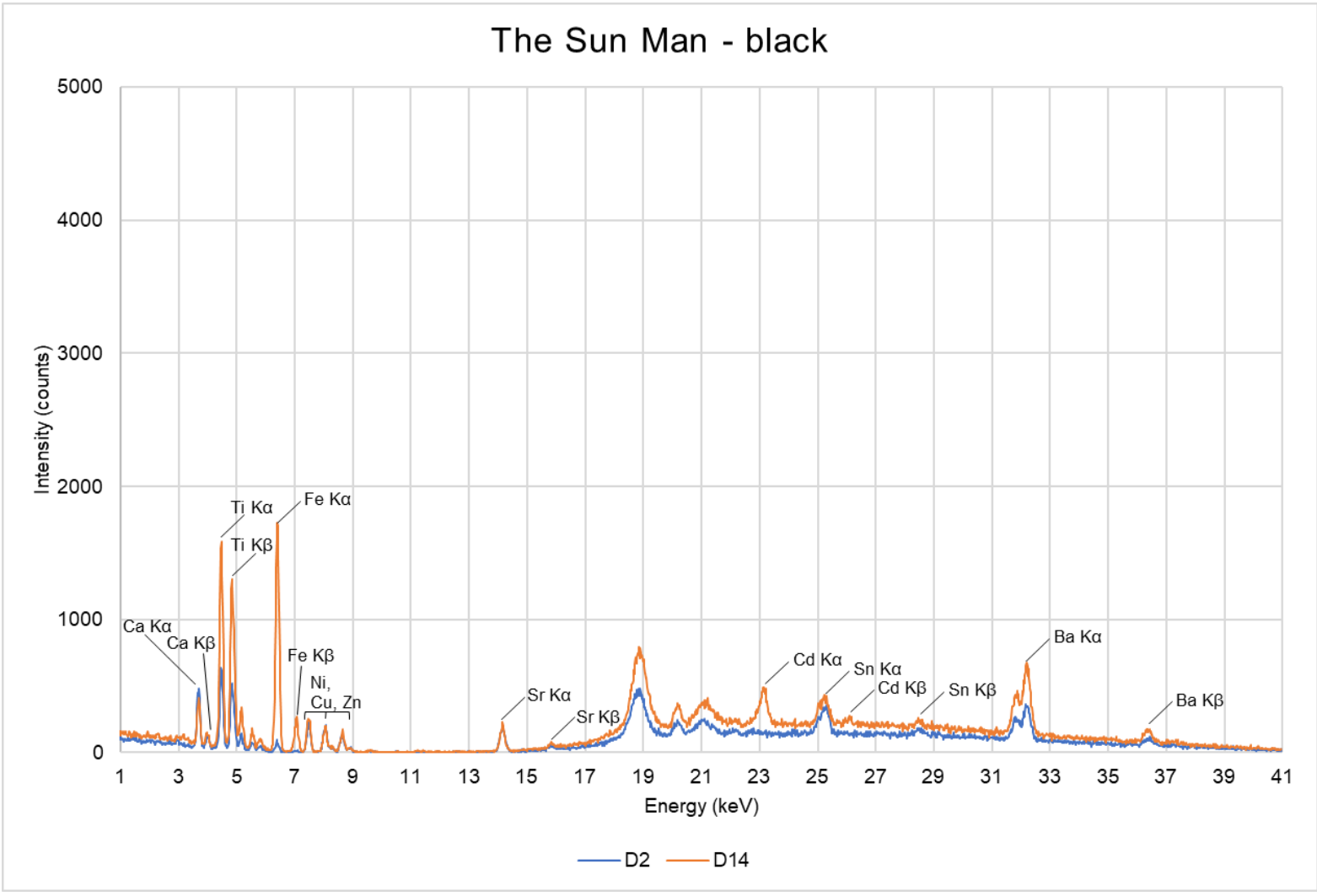

Figure 18: Elemental peaks of locations D2 and D14 on The Sun Man (1995).

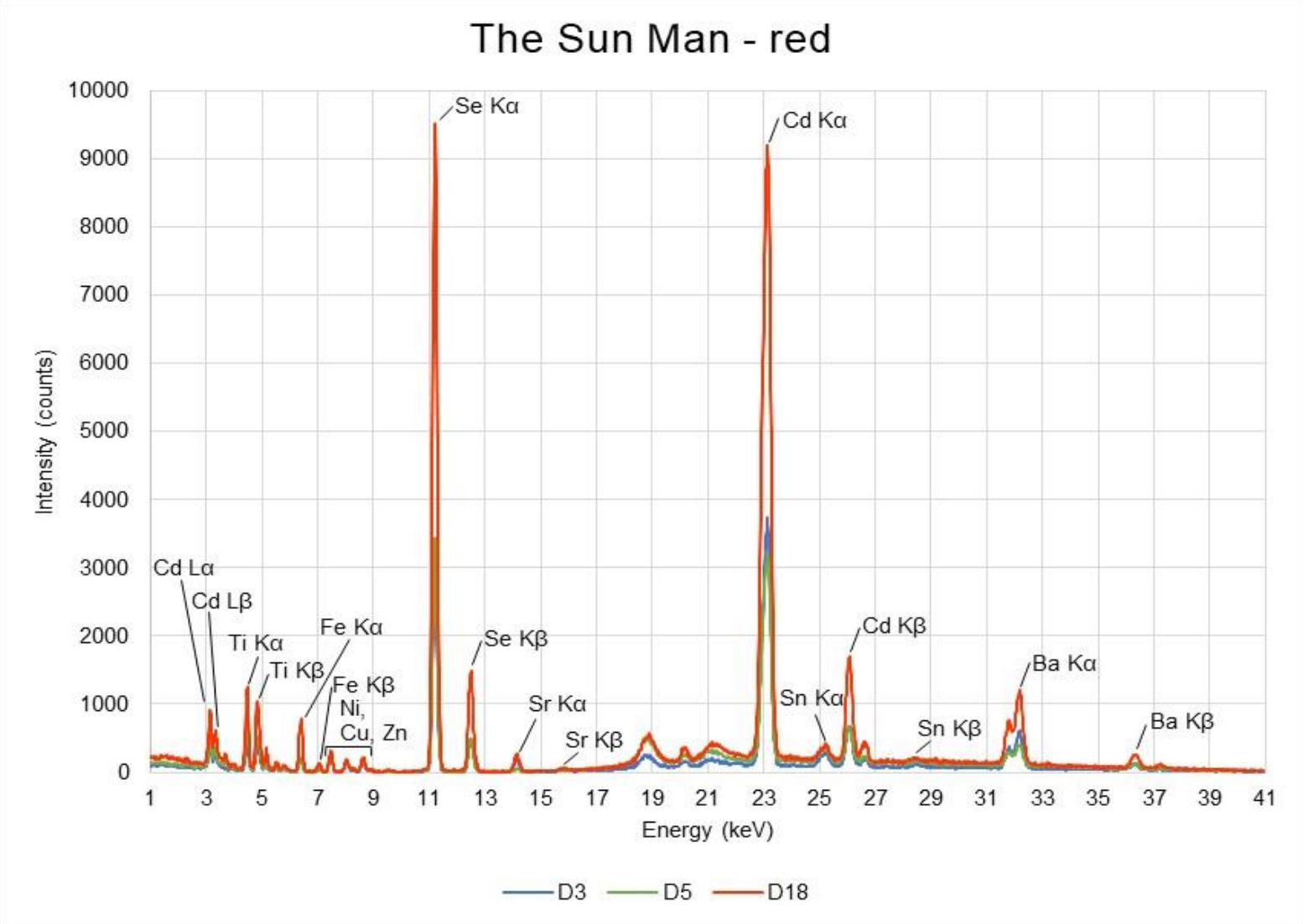

Figure 19: Elemental peaks of locations D3, D5 and D18 on The Sun Man (1995). 


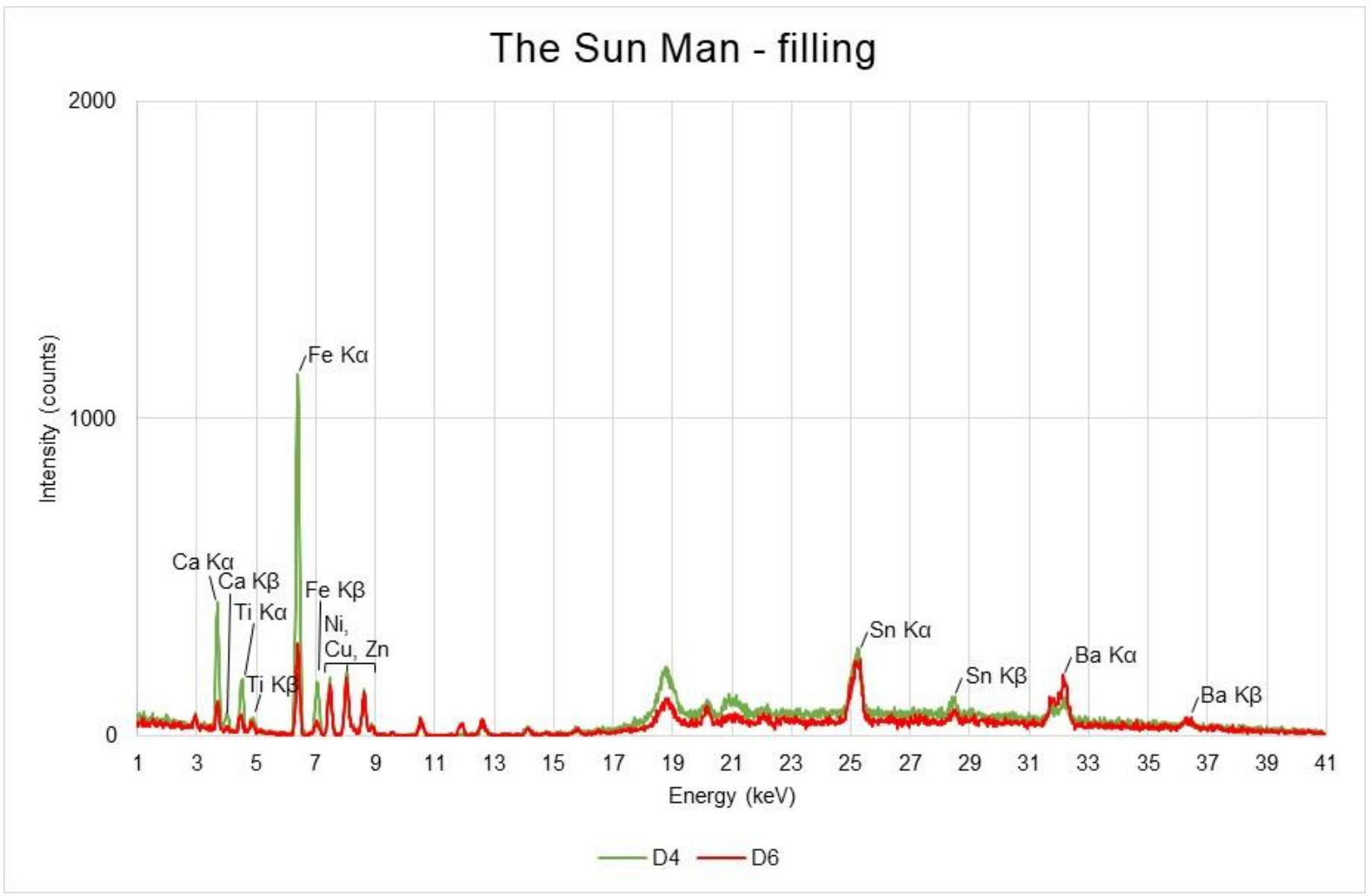

Figure 20: Elemental peaks of locations D4 and D6 on The Sun Man (1995).

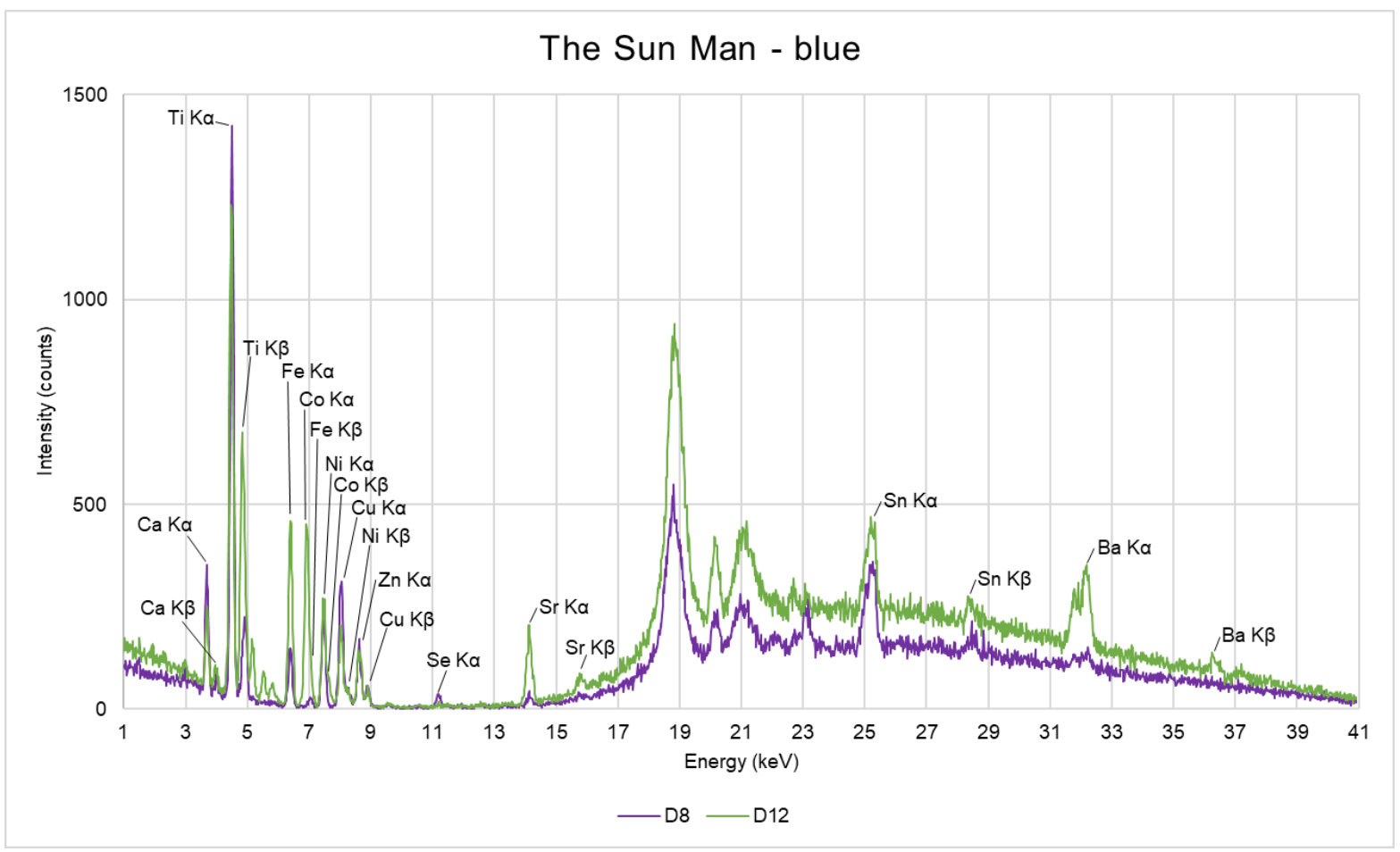

Figure 21: Elemental peaks of locations D8 and D12 on The Sun Man (1995). 
Pharos Journal of Theology ISSN 2414-3324 online Volume 102 - Special Ed 1 (2021)

Copyright: @2021 Open Access/Author/s - Online @ http//: www.pharosjot.com

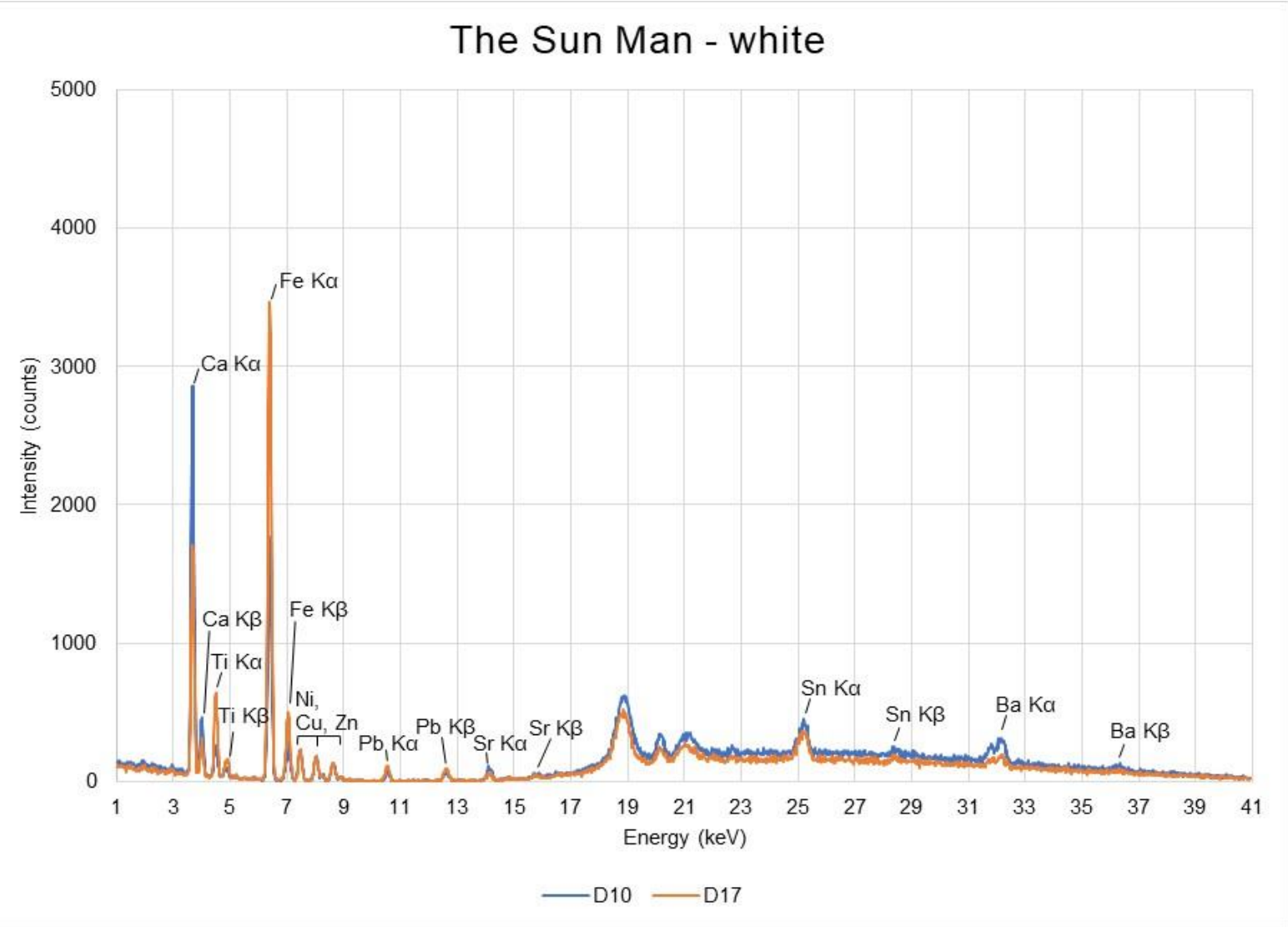

Figure 22: Elemental peaks of locations D10 and D17 on The Sun Man (1995).

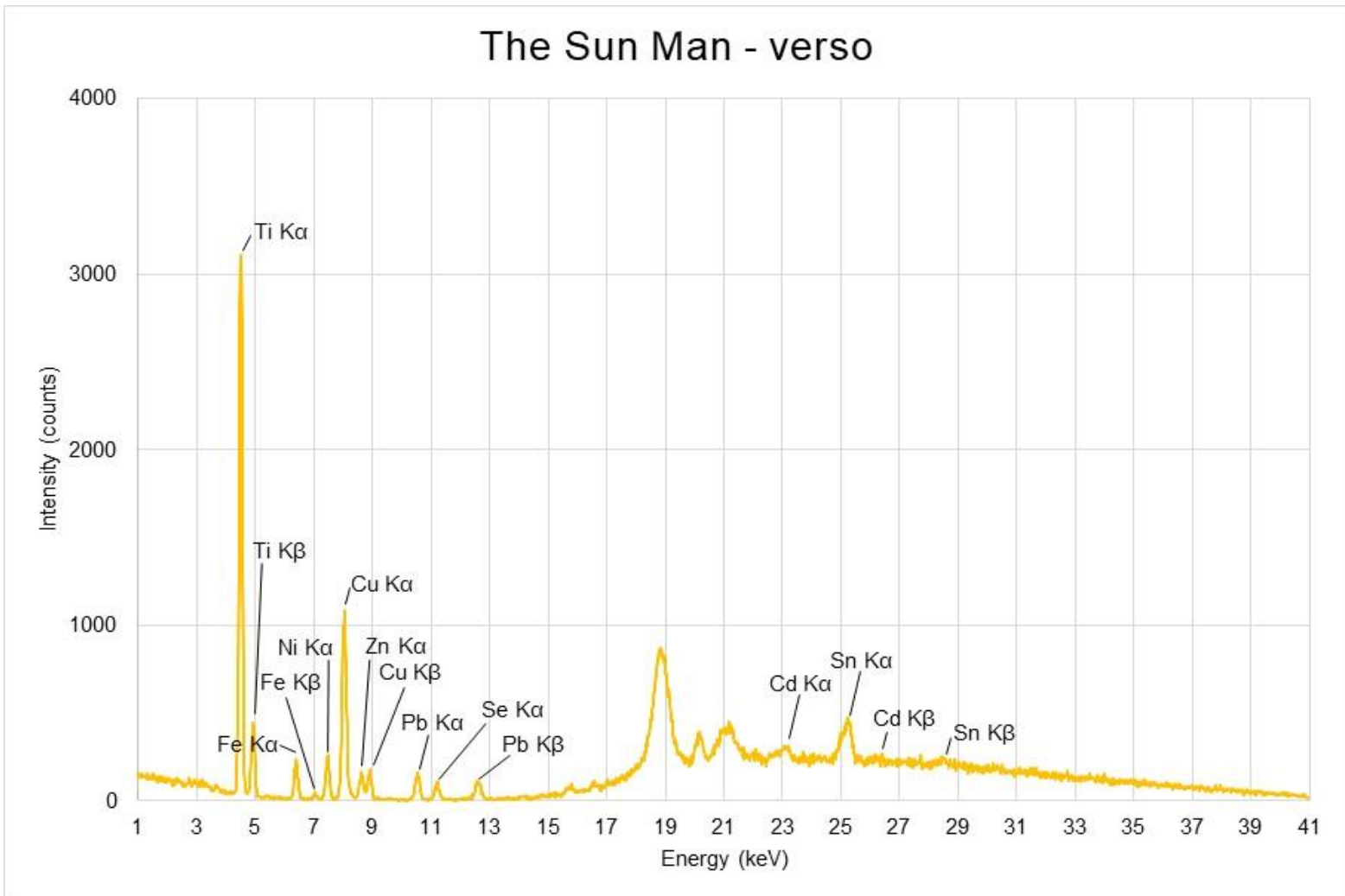

Figure 23: Elemental peaks of location D19, the verso, on The Sun Man (1995). 
Paints consist of pigments in a carrier, forming a suspension that can be evenly spread over the substrate. The carrier is either an oil such as linseed oil or acrylic. When following the flowchart for the characterisation of several classes of synthetic polymers by Derrick, Stulik and Landry (2000: 111), it is evident, based on the intensities' strength, absence, or weaknesses, that in The Sun Man, Sibiya uses the pigments identified in XRF, in an acrylic medium.

It is of significance to the analysis of different Sibiya artworks with XRF Spectroscopy that titanium, barium, chalk, and gypsum are observable in multiple Sibiya locations. The data also showed traces of aluminium dioxide $\left(\mathrm{Al}_{2} \mathrm{O}_{3}\right)$, silica $\left(\mathrm{SiO}_{2}\right)$, and magnesium oxide $(\mathrm{MgO})$. These elements can be detected owing to their presence as fillers, extenders, or thickening agents. According to Tom Learner ([sa]: 10), common extenders in modern paints are barium sulphate (which presents with trace elements of strontium - also in most of the locations), calcium carbonate (chalk), calcium sulphate (gypsum), aluminium dioxide, and silica. Silica $\left(\mathrm{SiO}_{2}\right)$ is associated with small quantities of titanium dioxide $\left(\mathrm{TiO}_{2}\right)$, calcium oxide $(\mathrm{CaO})$, and magnesium oxide (MgO) (Gysau, 2017: 27).

An alternative explanation for the presence of calcium, aluminium dioxide $\left(\mathrm{Al}_{2} \mathrm{O}_{3}\right)$, silica $\left(\mathrm{SiO}_{2}\right)$, magnesium oxide (MgO), and even iron (Fe) is found in the process of Cecil Skotnes' (19262009) artistic technique. In a personal communication with Pippa Skotnes (b. 1957) on 9 October 2020, she confirmed that her father, Sibiya's mentor and teacher, used acrylic paints mixed with raw pigment and marble dust to enhance his panel paintings' appearance. It would thus make sense if Sibiya had followed Skotnes' example, because marble dust consists of calcium oxide, aluminium dioxide, silica, magnesium oxide, and ferric oxide (Singh \& Madan, [sa]: [sp]).

With regard to the detection of nickel, copper and zinc at all locations on The Sun Man, it was found that a wood preservative named copper 8-quiolinolate has been in use since 1969. If it is an option for the explanation of the presence of copper and nickel, because it is manufactured by the condensation of copper 8-quinolinolate and nickel 2ethyl hexoate (Hafizoğlu, [sa]: [sp]). Other waterborne wood preservatives account for the presence of zinc, such as "zinc chloride, zinc metaarsenite (ZMA), copperised chromated zinc chloride (CuCZC), chromated zinc arsenate (CZA), and copperised chromated zinc arsenate (CuCZA) (Hafizoğlu, [sa]: [sp]). Copper compounds such as copper (II) sulphate and other copper salts; organocopper compounds, and zinc (II) chloride and other zinc salts (Unger, Schniewind \& Unger, 2001: 169, 173, 233) are also used for the preservation of wood.

\section{Conclusion}

It is remarkable that the use of language throughout this article - it may be this, it is possibly that - more closely resembles the inferences and suggestions characteristic of research in the humanities rather than the certainties often erroneously exacted from the 'hard sciences', such as chemistry. Just like the alchemists of old, modern chemists do not have a philosopher's stone, no single method that magically reveals all the secrets. We learn from experience, and even then, the answers are sometimes not clear cut.

But true to any scientific method, it is the consistent accumulation of data that eventually gives us the statistical ability to prove a hypothesis. This confirms why this research is so crucial in the African context: we do not have any databases regarding the materiality of African heritage objects, and this leaves us quite vulnerable to fraud and other consequences of our inability to prove the provenance of objects. With the case studies discussed in this article, we have demonstrated the potential of procedures like these to obtain information that could never have been determined irrefutably by connoisseurship and other techniques commonly used 
to determine authenticity. Over time, we will be able to build up the databases we need to assist with the provenance of heritage objects of Africa.

The only way to learn more about the materiality of heritage objects is the scientific study of the materials used in their creation, and in this way, we manage to reveal that which the artist may not even have been aware of. The interaction between atoms and molecules gives us an insight into the artwork that elevates our experience to a different level. Colleagues in chemistry departments may disagree, but analytical chemistry is an art form - or at least, an accelerated means of art appraisal in so far as it enhances an appreciation for the spiritual effect of the heritage object as effected through material processes.

\section{References}

Anonymous. (1996). Lucky Sibiya. Pretoria: University of Pretoria. [Catalogue].

Bester, R. (Ed) (2007). Figure/Ground: Reflections on the South African Reserve Bank Art Collection. Johannesburg: South African Reserve Bank.

Bezur, A., Lee, L., Loubser, M. \& Trentelman, K. (2020). Handheld XRF in Cultural Heritage: A Practical Workbook for Conservators. Los Angeles: Getty Conservation Institute.

Bezur, A. \& Sperber, R. (2016). Instrumental Analytical Techniques for Cultural Heritage: Technique Overview. Unpublished handout. New Haven, USA: Institute for the Preservation of Cultural Heritage.

Cycleback, D. (2017). Authenticating Art and Artifacts: An Introduction to Methods and Issues. [SI]: Hamerweit Books.

Everard Read. [Sa]. Lucky Sibiya. [O]. Available online at: [https://www.everard-read-capetown.co.za/artist/LUCKY_SIBIYA/biography/] Accessed 12 February 2019.

Chatwal, G.R. \& Arora, M. (2009). Synthetic Dyes. New Delhi: Himalaya Publishing House.

Frey, F., Heller, D., Kushel, D., Vitale, T. \& Weaver, G. (2008). The AIC Guide to Digital Photography and Conservation Documentation, edited by J Warda. 3rd ed. Washington, DC: The American Institute for Conservation of Historic and Artistic Works.

Hamilton, C. (201)7. The long southern African past: enfolded time and the challenges of archive. Social Dynamics, v43 n3: 338-357.

Healing Scroll. [Sa]. [O]. Available online at: [https://www.metmuseum.org/art/collection/search/320962] Accessed 15 March 2021.

Johnston-Feller, R. (2001). Color Science in the examination of museum objects: nondestructive procedures. Los Angeles: Getty Publications.

Jordanova, L.J. (2012). The Look of the Past: Visual and Material Evidence in Historical Practice. Cambridge: Cambridge University Press. 
Le Roux, S. (2020). A technical survey of Lucky Madlo Sibiya's (1942-1999) materials and techniques employed in his carved and painted wood panel artworks. Unpublished Masters dissertation, University of Pretoria, South Africa.

Mercier, J. (1979). Ethiopian Magic Scrolls. New York. Publisher?

Mdanda, S. (2007). Lucky Sibiya (1942-1999), in Figure/Ground: Reflections on the South African Reserve Bank Art Collection, edited by R Bester. Johannesburg: South African Reserve Bank.

Nilson, T. \& Thorell, K. (2018). Cultural Heritage Preservation: The Past, the Present and the Future. Halmstad. Publisher?

Steyn, R. (2012). Christian Divine, Holy and Saintly Protection of African Rulers, In The Byzantine 'Coptic' Iconographic Tradition. Unpublished PhD thesis, University of Johannesburg, South Africa. Retrieved from https://ujdigispace.uj.ac.za Accessed: 02 February 2018.

Stuart, B. (2007). Analytical Techniques in Materials Conservation. Chichester: John Wiley. 